\title{
INTEGRATED REPORTING DISCLOSURES AND FIRM VALUE OF LISTED INSURANCE COMPANIES IN NIGERIA
}

\author{
Appah Ebimobowei (Ph.D, FCA) ${ }^{1}$ and Onowu Joseph Uche \\ ${ }^{1}$ Isaac Jasper Boro College of Education, Sagbama, Bayelsa State, Nigeria. \\ Email: appahebimobowei@yahoo.com; Tel: +2348037419409 \\ ${ }^{2}$ Department of Accounting, Faculty of Business Studies, Ignatius Ajuru University of \\ Education, Port Harcourt, Rivers State, Nigeria.
}

\section{Cite this article:}

Appah E., Onowu J.U. (2021), Integrated Reporting

Disclosures and Firm Value of Listed Insurance Companies in Nigeria. African Journal of Accounting and Financial Research 4(2), 55-76. DOI: 10.52589/AJAFR-

WQIAKPZY.

\section{Manuscript History}

Received: 1 April 2021

Accepted: 22 April 2021

Published: 3 May 2021

Copyright $\left({ }^{\circ} 2020\right.$ The Author(s). This is an Open Access article distributed under the terms of Creative Commons AttributionNonCommercial-NoDerivatives 4.0 International (CC BY-NC-ND 4.0 ), which permits anyone to share, use, reproduce and redistribute in any medium, provided the original author and source are credited.
ABSTRACT: This study empirically investigated integrated reporting and corporate financial performance of listed insurance companies in Nigeria for the period 2010 to 2019. The study employed ex post facto and correlational research design. The sample size of the study consisted of insurance firms listed on the Nigerian Stock Exchange. The data for the study was obtained from the published annual financial statements of the sampled insurance companies and descriptive statistics, diagnostic test, unit root test, was used for data analysis while multiple regression analysis for the test of hypotheses. The result from the regression analysis revealed that integrated reporting positively and significantly affects the corporate financial performance of listed insurance firms in Nigeria. Also the control variables of debt, liquidity, corporate size and risk suggested both negative and positive significant influence on corporate financial performance of listed insurance firms in Nigeria. The paper concluded that integrated reporting affects the corporate financial performance of listed insurance companies in Nigeria. Therefore, the paper recommends amongst others that the Financial Reporting Council of Nigeria (FRCN) should make the adoption of integrated reporting compulsory across companies listed on the Nigerian Stock Exchange in a bid to improve the relationship between integrated reporting and financial performance of firms.

KEYWORDS: Integrated Reporting, Financial Performance, Liquidity, Corporate Size. 


\section{INTRODUCTION}

The need for a better and comprehensive reporting framework of the various activities of businesses necessitated the establishment of integrated reporting. This is why El Deeb (2019); Alessandro, et al (2018); kilic and Kuzey (2018); Ahmed-Haji and Anifowose (2017); Baboukardos and Rimmel (2016) stated that traditional reporting is extensively old fashioned for being too long and concentrating purely on the financial activities of business performance. Serafeim (2015); Hoque (2017) stated that traditional reporting has been criticized for its shortterm performance and value creation as well as its historic focus with the lack adequate disclosure regarding risks and uncertainty. Adeboyegun, et al (2020) noted that traditional methods of corporate reporting have been faced with the absence of transparency that brought about the need for the convergence of both financial and non-financial information into one document called integrated reporting. El-Deeb (2019) stated that integrated reporting is a wider process that contributes to long term value creation and corporate performance in the society. Adegbie, et al (2019); Feng, et al (2017); Fernando, et al 2017) averred that integrated reporting framework explains the creation of value over time for the providers of financial capital and means of prioritizing information needs of investors, so as to improve the usefulness of financial reporting through the enhancement of the value relevance of accounting information in any given organization.

The relevance of integrated reporting in modern accounting lexicon cannot be overemphasized. Adeboyegun et al (2020) noted that the benefits of integrated reporting framework is becoming generally acceptable and has evolved to be an area of interest to researchers and professionals. However, there are still relatively few studies on integrated reporting ideas on companies (Rinaldi et al., 2018) and there is still a dearth of evidence (Lee \& Yeo, 2016). In addition, examining integrated reporting on firm value is still one of the interesting topics for companies and regulators (Nurkumalasari, et al, 2019; Adegbie, et al 2019). The studies conducted by Lee \& Yeo (2016); Barth et al. (2017); Cosma, Soana \& Venturelli (2018); Adegbie, et al (2019) suggested a positive association between integrated reporting and firm value while a similar investigation by Nurkumalasari, et al (2019) indicated that integrated reporting does not affect the value of a firm. Therefore, existing studies in accounting literature have generated mixed results as regards integrated reporting and firm value. The inconclusive results have made the growth effect of integrated reporting debate open to further study. The gaps in terms of location (Yasseen \& Padia, 2018; Vitezic \& Petrlic, 2018; Ahmed Haji, A. \& Anifowose, 2017; Feng, et al, 2017; Setia, et al, 2015; Ernst \& Young, 2014), literature and methodology (Adeboyegun et al, 2020; Adegbie, et al, 2019; Nurkumalasari, et al, 2019).

Hence, in an effort to improve on prior empirical investigation and fill the research gap, this study investigates integrated reporting and firm value of insurance companies in Nigeria. This study was motivated by the fact that there are few studies (e.g. Adeboyegun et al, 2020; Adegbie, et al, 2019; Iyoha, et al, 2017) on integrated reporting and firm value in Nigeria. Therefore, to achieve the purpose of this paper, the following specific objectives were answered in this study:

1. To investigate the relationship between integrated reporting disclosures and firm value of listed insurance companies for the period 2010 to 2019 in Nigeria.

2. To determine the relationship between liquidity and firm value of listed insurance companies for the period 2010 to 2019 in Nigeria. 
3. To evaluate the relationship between the debt policy and firm value of listed insurance companies for the period 2010 to 2019 in Nigeria.

4. To examine the relationship between corporate size and firm value of listed insurance companies for the period 2010 to 2019 in Nigeria.

5. To investigate the relationship between corporate risk and firm value of listed insurance companies for the period 2010 to 2019 in Nigeria.

The following research questions were answered in this study:

1. What is the relationship between integrated reporting disclosures on firm value of listed insurance companies for the period 2010 to 2019 in Nigeria?

2. What is the relationship between liquidity on firm value of listed insurance companies for the period 2010 to 2019 in Nigeria?

3. What is the relationship between debt on firm value of listed insurance companies for the period 2010 to 2019 in Nigeria?

4. What is the relationship between corporate size on firm value of listed insurance companies for the period 2010 to 2019 in Nigeria?

5. What is the relationship between corporate risk on firm value of listed insurance companies for the period 2010 to 2019 in Nigeria?

The following hypotheses were answered in this study:

Ho1: Integrated reporting disclosure has no significant effect on firm value of listed insurance companies for the period 2010 to 2019 in Nigeria.

Ho2: Liquidity has no significant effect on the firm value of listed insurance companies for the period 2010 to 2019 in Nigeria.

Ho3: Debt policy has no significant effect on firm value of listed insurance companies for the period 2010 to 2019 in Nigeria.

Ho4: Firm size has no significant effect on firm value of listed insurance companies for the period 2010 to 2019 in Nigeria.

Ho5: Corporate risk has no significant effect on firm value of listed insurance companies for the period 2010 to 2019 in Nigeria.

\section{LITERATURE REVIEW}

\section{Conceptual Review}

The conceptual review of this study examines integrated reporting and firm value within the context of the various dimensions of the topic consistent with previous study investigated between integrated reporting disclosure and firm value. 
Concept of Integrated Reporting: Integrated reporting is an emerging accounting framework that discloses both financial and non-financial information of a business entity. According to Adeboyegun et al, 2020; Adegbie, et al, 2019; Hsiao \& Kelly (2018), McNally, et al (2017); IIRC (2013) integrated reporting is an effective way of communicating the strategy, governance, prospects and performance, in the context of its external environment, that can help in initiating the formation of the firm value over the short, medium and long term horizon within an entity. Integrated reporting is a principled-based framework that is based on the principles of strategic focus and future orientation, stakeholder relationships, connectivity of information, materiality, conciseness, reliability and completeness as well as consistency and comparability (Adeboyegun et al, 2020; IIRC, 2015). Ara and Harani (2020) averred that integrating reporting is a method grounded on social world stories that satisfies the proactive actions of various stakeholders. Aluchna et al (2019) argues that integrated reporting is the reflection of the processes of an entity that explains the meaning to actions, events and objects that provides guidance to bring reality. Camilleri (2018) maintained that integrated reporting begins with financial disclosure that covers non-financials with highlights to ESG. Dumay (2016) noted that the adoption of an integrated reporting method is expected to enhance the effectiveness of internal control systems and to support the achievement of sustainability of the overall performance, thus boosting the value creation of the corporation.

However, several studies provide results about the purpose of integrated reporting (e.g., Zhou, et al, 2017; Cahan, et al 2017). The primary objective of integrated reporting is to improve on the quality of information available to providers of capital, to shareholders or to investors by communicating broader and more relevant information that can assist in decisions making (IIRC, 2013). IIRC (2015) suggests that investors apply integrated for purposes of managing investment risk, evaluating industry dynamics and the regulatory environment, and assessing a company's forward-looking information. El-Deeb (2019); Lai, et al (2018); Adams, (2015) explained that integrated reporting describes the accountability for the various capital in an entity such as natural, manufactured, intellectual, human and social resources. Van Bommel (2014) noted that integrated reporting is a hybrid reporting framework that covers the different aspects of financial and sustainability reporting by providing a true and fair view of the firm value and thereby accounting for sustainability.

International Integrated Reporting Council (2013) provides a framework for integrated reporting divided into the following: organizational overview and external environment, governance reporting, business model reporting, risk and opportunity reporting, strategy and resource allocation reporting, performance reporting, outlook reporting, basis of preparation and presentation reporting.

Organizational Overview and External Environment: The organizational overview provides an explanation of the mission and vision of the business. According to Adegbie et al (2019a), organizational overview explains the affair of the business as it relates to the mission and vision statement of the business. Udofia et al (2020) suggest that organizational view and external environment provide an explanation of the organizational activities, business environment, ethical issues, board structure, market position and the influence of the environment and structure. The International Integrated Reporting Council (2013) stated that this component of the framework explains culture, ethics, values, ownership, principal activities, operating structure and markets. Olusanjo et al (2019), Adegbie, et al (2019b) noted that the external environment is made of factors that influence the business externally such as legal, commercial, political, sociological, demographical, global, technological, customer 
preference and associated industries etcc. These organizational overview and external environment issues are found in the annual reports of listed companies in Nigeria (Udofia, et al, 2020).

Governance Reporting: The governance reporting element of integrated reporting explains the competences, skills and qualifications of members of the Board of Directors and their various contributions to the corporate value creation, risk management, cultural and ethical values in the organization (Udofia, et al, 2020). Adegbie, et al (2019a), noted that governance reporting explains the communication of the culture, leadership structure, competences, skills, and ethical values of members of the Board of Directors.

Business Model Reporting: This element of integrated reporting framework explains the logic of the business, operational modalities and the value creation of the various stakeholders (Sukhari \& De-Villiers, 2018; Olusanjo et al, 2019). It is a model that shows how an organization transforms inputs through its business operations into outputs and outcomes with the purpose of achieving corporate strategic goals and value creation in the short, medium and long term (IIRC, 2013; Olusanjo et al, 2019). Ernst and Young (2014) noted that business model is a major element of integrated reporting because it provides an important engagement with the users of financial statements. Udofia et al (2020) noted that this model explains the most important capital of business such as human, natural, social, intellectual, financial and manufactured capital.

Risk and Opportunity Reporting: This element of integrated reporting framework explains the impact of risk and opportunities available to the business from the internal and external environment (Udofia, et al 2020). According to Scantlebury and Alleyne (2015), risk and opportunity reporting is an attempt to communicate to users of financial statements the prospective opportunity and risk that affects the future of the business. Wen and Heong (2017), state that risks are corporate hazards that are converted into better opportunities for corporate investment. According to Lipunga (2015), the reporting of risk and opportunity involves the assessment of the likelihood of each item of risk and opportunity, potential magnitude and strategies to handle risk and opportunities available to businesses.

Strategy and Resource Allocation Reporting: This element of integrated reporting framework is concerned with corporate mission, vision and strategies to achieve the objectives of the business (Udofia, et al, 2020). Grant ((2016) noted that the purpose of strategy is the formation of plans of the business intentions in the achievement of corporate goals taking into consideration the suppliers, customers, and the society in which it operates, activities as well as the resource allocation of the organization. Adegbie et al (2019a) states that the strategies have to do with the implementation of strategic objectives and resource allocation has to do with the implementation of strategy.

Performance Reporting: The performance reporting of integrated reporting framework explains the qualitative and quantitative information about performance such as targets, risks and opportunities with explanation of their significance, implications, methods and assumptions utilized in the preparation (Adegbie, et al, 2019). According to Udofia et al (2020), performance reporting shows the financial and non-financial measures employed to show the ability of the business to achieve its strategic corporate objectives with the assistance of the various capitals and the influence of corporate activities on the value of each capital. 
Outlook Reporting: The outlook reporting of integrated reporting framework explains that businesses should disclose relevant information on the challenges faced by organisations when pursuing their strategy, the implications of environmental uncertainties on the organization and value creation with the long-term performance (Lipunga, 2015). The International Integrated Reporting Council (2013), states that the framework shows the challenges and uncertainties organisations encounter in pursuing corporate strategy and the implications for business model and performance. The Council also noted that integrated reporting reveals the changes over time and information established on sound and transparent analysis of corporate expectations of the external environment that affects the short, medium and long term objectives.

Basis of Preparation and Presentation Reporting: This element of integrated reporting framework explains the information to be disclosed in an integrated report and the basis of measurement and evaluation of the financial report (Udofia et al, 2020). According to Adegbie, et al (2019), Olusanjo et al (2019), an integrated report shows the basis of preparing and presenting financial reports with the materiality determination, reporting boundaries and determination of frameworks and methods applied to assess material issues.

Concept of Firm Value: There are several interpretations given to the concept of value. Adegbie, risk (2019) stated that value can be explained from the concept of fair market value, fair value, investment value, and intrinsic value. Similarly, Moeljadi and Supriyati (2014) noted that value can be described as firm value, among others as nominal value, market value, intrinsic value, book value and liquidation value. They noted that the most representative concept to determine corporate market performance was intrinsic value, but it is difficult to estimate and it requires the ability to identify significant variables that influence the profitability of a company. Therefore, firm value is the sum of the actual market value of ordinary shares and estimated market value of preference shares and debt. In the same vein, Damodaran (2005) stated that firm value is the perception of the investor to the success of a firm. It is reflected in the share price of the corporation. Adegbie, et al (2019) noted that the increase of the share price shows the confidence of the investors to the firm, so they are willing to pay more with aim for higher financial returns. Therefore, the value of a firm is the total assets owned. It consists of the market value of share and liabilities.

The value of a firm is influenced by several fundamental factors of the firm such as liquidity (Azmat 2014; Chen, et al 2016; Van-Heerden and Van-Rensburg 2016), debt policy (González 2013) and investment decisions (Golec \& Gupta 2014; Abreu 2016). Hidayat, et al (2019) maintained that liquidity, debt policy, and firm investment decisions do influence firm value if the liquidity conditions are good and the debt policy in relation with the needs and investment decisions are made precisely. Hidayat, et al (2019) maintained that investors view firm value from stock prices, stock returns, earnings per share (EPS), price earnings ratio (PER), Tobin's $\mathrm{Q}$, and price to book value (PBV). Adegbie, et al (2019) further stated that firm value can be measured using accounting-based indicators such as return on asset, return on equity, price earnings ratio and price to book value while the market valued based indicator usually applies Tobin's Q. It is defined as (total assets plus market value of ordinary shares minus book value of ordinary shares minus deferred tax) divided by total assets. Tobin's Q is used to measure firm value which shows management performance in managing the firm assets. Its value describes a condition of investment opportunities owned by the firm or the firm growth potential (Adegbie, et al 2019; Hidayat et al, 2019). 


\section{Theoretical Review}

There are several theories associated with integrated reporting disclosures. These theories include that of stakeholder theory by Freeman (1984), legitimacy theory by Lindblom (1994), agency theory by Jensen \& Meckling (1976) as well as signaling theory by Spence (1973).

Stakeholder Theory: This theory is one of the theories used to explain voluntary disclosures. Freeman (1984) stated that a stakeholder is an individual or group that can affect the achievements of the corporate objectives or is or are affected by these objectives. Adeboyegun et al, (2020) stated that these entities include the owners, managers, employees, suppliers, payables, receivables, government, and the public. Gray, Owens \& Adams (1996) suggested that this theory acknowledges the dynamic and complex relationships between corporations and their stakeholders and that these associations involve responsibility and accountability. This theory consists of both ethical and managerial components. The ethical component provides that all stakeholders should be treated equally while the managerial component explains that the more powerful stakeholders are of greater interest to the corporation. The corporation will satisfy the demands of the powerful stakeholders because they are essential for corporate survival. Therefore, an integrated report must be prepared to provide details, which can comprehensively meet the information needs of the diverse stakeholders (Adeboyegun et al, 2020). Camilleri, (2018); de Villiers, et al (2017); Dumay, et al. (2018) as well as Aluchna, et al., (2019) explained that integrated reporting explains how important stakeholders can drive management behaviour towards society and environment rather than profit motives only.

Legitimacy Theory: This is a theory that explains the legitimacy of an entity to exist for the purpose of meeting public needs. Lindblom (1994) noted that this theory assumes that a corporation has the right to exist unless its values are in congruence with that of the society at large where it operates. This theory explains that there is a social contract between a company and the society. The theory of legitimacy primarily maintains ethical behaviour of firms, to function in a certain economy (Aluchna, et al 2019). Hence corporations should stick to this contract otherwise they may damage their own legitimacy and relevance to society. Therefore, corporations should use the information in an integrated report to disclose the financial and non-financial information so as to maintain their legitimacy to the society. Aluchna, et al (2019) stated that integrated reporting is anchored around legitimacy theory that explains the connectivity, balance and reputational risk to fulfil stakeholders' expectations.

Agency Theory: This theory of Jensen \& Meckling (1976) assumes that every corporation has a form of principal-agent relationship within the walls of its structure. Jensen and Meckling (1976) defined the agency relationship as a contract under which one or more persons (the principal) engage another person (the agent) to perform some service on behalf which involves delegating some decision-making authority to the agent. Adeboyegun et al (2020) suggested that this theory assumes that managers are likely to engage in tendencies by making use of corporate resources for activities that would most likely benefit them more than the owners. According to this theory, the principal and agent are basing their decisions in their own selfinterest. Hence, there is a conflict that results in information asymmetry. Hence, the information-asymmetry is the outcome of the agency problem. The information-asymmetry leads to the problem of agency costs. Therefore, integrated reporting provides that information must be made available in a comprehensive manner that will reduce the information asymmetry. 
Signaling Theory: This theory was developed from the work on labour markets by Spence (1973) that shows the selection ability of prospective employers that is affected as job applications engage in behaviours that reduce information asymmetry. This theory was used to explain the information asymmetry and was used to explain voluntary disclosure in corporate reporting (Adegbie, et al, 2019). Hence, voluntary disclosure explains the signaling process in which corporations disclose more information than the mandatory disclosure that is required by laws and regulations in order to provide that they are better. Dumay, et al (2018) explain that this theory describes the behaviour of the sender, who focused on how to communicate and the receiver, who focused on how to infer the received signal. Fernando, et al (2017) further averred that the credibility of integrated will send the signal to various stakeholders about the corporation in order to meet their information expectancy. Aluchna, et al., (2019) argue that signaling theory attempts to explain the corporation's action that may not certainly be rooted in its own culture.

\section{Empirical Review}

This section of the study of integrated reporting and firm value of insurance companies in Nigeria examined prior studies on integrated reporting, liquidity, debt policy, profitability and corporate size on firm value in Nigeria.

\section{Integrated Reporting and Firm Value}

Jeroe (2016) investigated the effect of integrated reporting and non-financial information on performance of 44 firms across the world for 2012 and 2013. The study used return on asset and earnings per share as dependent variables and also used integrated reporting index, nonfinancial information disclosure index, firm size, risk as well as the market book value of the firm as independent variables with the use of descriptive statistics and pooled regression analysis technique. The study suggested that integrated reporting and non-financial information reporting negatively influence the performance of firms.

Suttipun (2017) investigated integrated reporting and financial performance of 150 firms between 2012 and 2015 in Thailand. The study employed tobin $\mathrm{q}$ as the dependent variable and also used financial capital reporting index, manufactured capital reporting index, intellectual capital reporting index, human capital reporting index, social capital reporting index, environmental capital reporting index as well as size of firm as independent variables coupled with the use of correlation and multiple Least Square regression analysis. The study showed that reporting of corporate social reporting issues as well as capital positively influences performance while environmental reporting negatively affects performance.

Albetairi, et al (2018) examined integrated reporting and financial performance of five insurance firms in Bahrain between 2012 and 2015. Their study employed business model index, risk and opportunities index, strategy and resource allocation index as well as performance disclosure index as indices of integrated reporting forming the independent variables while Return on Assets was employed as the dependent while the pooled ordinary least square regression technique, it was divulged that integrated reporting indices have mixed influence on firm performance to the end that risk and opportunities index as well as performance index negatively affects performance. 
Cosma, et al (2018) studied integrated reporting and firm value in South Africa between 2013 and 2016. The study employed firm value proxied by stock returns as dependent variable while integrated reporting as proxied by the national market index return, which is the response of the public to integrated reporting was used as the independent variable while the ordinary least square regression techniques was employed for data analysis. Their findings showed that integrated reporting positively influences firm performance.

Soumillon (2018) analysed the value relevance of integrated reporting of 63 firms in South Africa in 2017. The investigation employed the adjusted market value of equity as the dependent variable and also utilized integrated reporting quality, corporate social responsibility performance, corporate governance as well as environmentally and socially sensitive index as independent variables. The study employed descriptive statistics as well as pooled ordinary least square regression analysis and the findings showed that integrated reporting do not significantly influence firm value.

Bijlmakers (2018) investigated the influence of integrated reporting on firm value of 56 banking firms in Europe between 2010 and 2016. The study utilised tobin q as the dependent variable and also employed integrated reporting index, size, growth, discretionary accruals, return on equity as well as earning quality as the independent variables. The study also used descriptive statistics and the POLS regression technique, and the findings showed that integrated reporting has no significant effects on firm value.

Nurkumalasari et al. (2019) carried out a study on integrated reporting disclosure on firm value of 14 firms in Asia between 2015 and 2017. The study utilized tobin q as the dependent variable and also employed the integrated disclosure index, number of subsidiaries, long-term debt ratio, return on asset, total debt ratio as well as assets as the independent variables. The data was analysed with descriptive statistics and POLS regression techniques and the result showed that integrated reporting has no effect on firm value especially in cases of high leverage.

El Deeb (2019) analysed integrated reporting on firm value and performance of firms listed in EGX30 index in the Egyptian stock exchange market between 2012 and 2017. The data for the study were obtained from the annual reports of the sampled companies and the data collected were analysed using descriptive analysis, Pearson correlation and regression analysis. The findings of the study revealed that integrated reporting index positively affects firm performance and value and the leverage level of the companies.

Adegbie, et al (2019) examined integrated reporting and the value of 38 consumer goods and industrial goods manufacturing companies listed on the Nigerian Stock Exchange for the period 2012 to 2016. Their study employed ex-post facto research design and purposive sampling technique. The data were obtained from the published financial statements of the sampled firms and the data collected were analysed with descriptive and inferential statistics using regression analysis. The results of their research found that integrated reporting significantly affects firm's value measured by Tobin's Q (TQ); disclosure of financial capital (DFC) negatively and significantly influence Tobin's Q; disclosure of manufactured capital (DMC) positively and insignificantly affects Tobin's Q; disclosure of intellectual and human capital (DIHC) negatively and insignificantly influences Tobin's Q; and disclosure of natural capital (DNC) negatively and insignificantly influences Tobin's Q. Firms' size (SIZE) and leverage (FLEV) had significantly controlled the influence of integrated reporting on Tobin's Q. 
Olusanjo et al (2019) examined integrated reporting practices on shareholders' relationships with manufacturing companies quoted on the Nigerian Stock Exchange as at 31 December, 2018. The study employed survey research design with a sample size of 45 and questionnaire method of data collection from 675 respondents using purposive sampling technique. The data were collected from a well validated questionnaire with Cronbach's alpha reliability coefficients of 0.73 to 0.85 . The data obtained were analysed using descriptive and inferential statistics. The study revealed that integrated reporting practices jointly significantly influence improved stakeholders' relationships.

Adeboyegun et al, (2020) investigated integrated reporting and performance of 13 banks in Nigeria for the period 2009 to 2018. The study employed cross sectional and ex post facto research design with data obtained from the annual reports of the sampled banks. The study employed profit after tax as dependent variable and also used integrated reporting index, debt to equity ratio and total assets as independent variables and the data were analysed with the use of classical ordinary least square and panel co-integration techniques. The data analysis showed that integrated reporting does not significantly influence corporate performance of banks in the short run, but significantly affects firm performance in the long run.

Liquidity and Firm Value: The nexus between liquidity and performance has received considerable attention in accounting and financial research from different perspectives. Studies have considered both the effect of liquidity on performance as well as the dependence of liquidity on performance. Research on the effect of liquidity on the firm value has been done by several scholars. Chen, et al (2016), Van-Heerden and Van- Rensburg (2016), Azmat (2014) and Prombutr et al. (2010) showed a positive effect of liquidity on firm value.

Debt and Firm value: The nexus between debt policy and firm value has been investigated by several authors. The research results of De Jong et al (2011) and Gonzales (2013) revealed that debt positively influences the value of a company. In contrast, the findings of Meier \& Laurin (2013), Cassell et al. (2012), and Akbar et al (2013) suggested that debt negatively affects the value of a firm. Dada (2014) analysed the nexus between profitability and debt of big firms in Nigeria. The study employed return on assets and return on equity as proxies for the performance of the company while debt of short term and long term were utilised in study as independent variables. The data collected from the published annual financial statement were tested using the fixed effect and panel data techniques. The results of his study suggested that if there is an increase in debt then the profitability of corporations' declines.

Corporate Size and Firm Value: Malik, et al (2014) examined the nexus between board size and firm performance using the Pareto Approach for 14 Pakistani banks for the period 20082012. The results of their study showed a significant positive association between board size and bank performance. Bebeji, et al (2015) examined board size and composition on the performance of 5 Nigerian banks for the period of 9 years. The study utilized multivariate regression analysis and their results showed that the board size has a significant negative effect on the performance of banks in Nigeria. Isik and Ince (2016) analysed board size and board composition on performance of 30 commercial banks from 2008 to 2012 in Turkey. After controlling for bank size, credit risk, liquidity risk, net interest margin and non-interest income, the results of panel fixed effects regression suggest that corporate size has a significant positive impact on bank's performance. Kajola, et al (2017) investigated corporate board size and financial performance of listed firms in Nigeria. The study was for a period covering 2003 to 2014 with ex post facto research design and correlational design with secondary data obtained 
from the published annual reports of the firms. Their study employed panel data regression analysis and Fixed effects model as estimation technique, the result revealed a positive and significant relationship between board size financial performance proxies (Return on assets and Return on equity).

Corporate Risk and Firm Value: The nexus between corporate risk and financial performance has received considerable attention in accounting and financial research from different perspectives. Studies have considered both the effect of corporate risk on financial performance as well as the dependence of corporate risk on financial performance. Mirza and Javed (2013) stated that the association between risk and returns should be properly managed to enable investors obtain the required yield from risk bearing investment opportunities. Onsongo, et al (2020), Kinyua et al. (2015); Were (2015) state that risk can provide favourable and unfavourable results which directly affects the potential yield. Mirza and Javed (2013) in their study revealed a positive relationship between risk and corporate performance. Chukwunulu et al (2019), Yunusa et al (2019) suggest that risk does not significantly affect the performance of firms. Muriithi (2016) stated that firm performance has a relationship with the level of risk managed by the organization (Onsongo et al, 2020).

\section{METHODOLOGY}

Research Design: This study employed ex post facto research design and correlational research design. This is because ex post facto research design is a systematic empirical inquiry in which the scientist does not have direct control of independent variables because they are inherently not manipulated (Appah, 2020). Egbunike and Abiahu (2017) stated that a correlational research design is the measurement of two or more factors to determine or estimate the extent to which the values for the factors are related or change in an identifiable pattern.

Population and Sample of the Study: The population of the study is made up of insurance companies quoted on the Nigerian Stock Exchange as shown on the Nigerian Stock Exchange Factbook for the year 2010 - 2019. Therefore, the sample size of this study is made up of ten insurance companies (Allco Insurance Plc, Leadway Assurance Plc, Custodian \& Allied Insurance Plc, Cornerstone Insurance Plc, AXA Mansard Insurance Plc, African Allied Insurance Plc, Goldlink Insurance Plc, Continental Insurance, Industrial \& General Insurance Plc \& Lasaco Assurance Plc) which were purposively selected on the availability of data during the years 2010 to 2019.

Source of Data Collection and Analysis Technique: The study employed secondary sources of data collection mainly from the published audited financial statements of each insurance company in Nigeria obtained from their website for the study period to analyse the effect of the independent variables on the dependent variables. The data collected were analyzed using descriptive statistics, diagnostic tests and multiple linear regression analysis of panel data for the years 2010 to 2019 .

Variables of the Study: The study employed dependent, independent and control variables. The dependent variable consists of tobin $q$ while the independent variable and control variables consist of integrated reporting, debt ratio, liquidity and corporate size. The variables were measured as follows: 
Table 1: Measurement of Variables

\begin{tabular}{|l|l|l|l|}
\hline Variables & Symbol & \multicolumn{1}{|c|}{ Measurement } & \multicolumn{1}{|c|}{ Source } \\
\hline Tobin Q & TBQ & $\begin{array}{l}\text { Total market value plus debt } \\
\text { value of company to total } \\
\text { asset value of company }\end{array}$ & $\begin{array}{l}\text { Nurkumalasari, et al, (2019); } \\
\text { Adegbie, et al (2019). }\end{array}$ \\
\hline $\begin{array}{l}\text { Integrated } \\
\text { Reporting }\end{array}$ & INR & $\begin{array}{l}\text { The number of integrated } \\
\text { reporting disclosed items } \\
\text { divided by maximum number } \\
\text { of disclosures }\end{array}$ & $\begin{array}{l}\text { Adeboyegun et al, (2020); } \\
\text { Nurkumalasari, et al (2019); } \\
\text { Soumillion (2018); Jeroe (2016) }\end{array}$ \\
\hline Debt Ratio & DER & $\begin{array}{l}\text { Total debt divided by total } \\
\text { assets }\end{array}$ & $\begin{array}{l}\text { Adeboyegun et al, (2020); De Jong } \\
\text { et al (2011) and Gonzales (2013) }\end{array}$ \\
\hline Liquidity & LQT & $\begin{array}{l}\text { Cash flows from operations } \\
\text { divided by total assets }\end{array}$ & $\begin{array}{l}\text { Chen, Yang \& Yeh (2016), Van } \\
\text { Heerden and Van Rensburg (2016), }\end{array}$ \\
\hline Corporate Size & COS & $\begin{array}{l}\text { Natural logarithm of assets } \\
\text { Nurkumalasari, et al (2019)'Kajola, } \\
\text { et al (2017) }\end{array}$ \\
\hline Risk & RSK & $\begin{array}{l}\text { Standard deviation of the } \\
\text { earnings before interest and } \\
\text { tax divided by total assets }\end{array}$ & $\begin{array}{l}\text { Yinusa, Ismail, Yulia, \& Olawale } \\
\text { (2019). }\end{array}$ \\
\hline
\end{tabular}

Source: Several Authors

Model Specification: Gujarati \& Porter, (2009) stated that model specification is the determination of the endogenous and exogenous variables to be included in the model as well as the a priori expectation about the sign and the size of the parameters of the function. The following model was developed based on the study variables:

\section{Model One}

$\mathrm{TBQ}=\beta_{0}+\beta_{1} \mathrm{INR}_{1 \mathrm{it}}+\beta_{2} \mathrm{DER}_{2 \mathrm{it}}+\beta_{3} \mathrm{LQT}_{3 \mathrm{it}}+\beta_{4} \mathrm{COS}_{4 \mathrm{it}}+\beta_{5} \mathrm{RSK}_{5 \mathrm{it}}+\varepsilon$

$\beta_{1}-\beta_{5}$ are the coefficients of the regression, while $\varepsilon$ is the error term capturing other explanatory variables not explicitly included in the model. The subscript, $i$, indicates the cross-sectional dimension of the panel data while the subscript, $t$, indicates the time series dimension. The $\mathrm{p}$ value shows what is the smallest level at which we would be able to accept the null hypotheses of a test. We used a 5\% level of significance; hence we conclude that the coefficient is significantly different from zero at the $5 \%$ level if the p-values is less than or equal to 0.05 . If it is greater than 0.05 then we cannot reject the null hypothesis that the coefficient is actually zero at our $5 \%$ significance level. 


\section{RESULTS AND DISCUSSIONS}

This section of the paper presents the results and discussion obtained from the data obtained from the annual reports of the sampled insurance companies in Nigeria.

Table 1: Descriptive Statistics

$\begin{array}{ccccccc}\text { Statistic } & \text { TBQ } & \text { INR } & \text { DER } & \text { LOT } & \text { COS } & \text { RSK } \\ \text { Mean } & 20.44000 & 10.05051 & 3.707071 & 1.000000 & 5.606061 & 0.616162 \\ \text { Median } & 17.88000 & 9.000000 & 3.000000 & 1.000000 & 6.000000 & 1.000000 \\ \text { Maximum } & 410.3900 & 17.00000 & 12.00000 & 1.000000 & 6.000000 & 1.000000 \\ \text { Minimum } & -51.97000 & 4.000000 & 1.000000 & 1.000000 & 3.000000 & 0.000000 \\ \text { Std. Dev. } & 47.29864 & 2.800779 & 2.408541 & 0.000000 & 0.890061 & 0.488794 \\ \text { Skewness } & 5.760055 & 0.317670 & 1.038719 & \text { NA } & -1.937357 & -0.477717 \\ & & & & & & \\ \text { Jarque-Bera } & 8985.019 & 2.284138 & 22.19227 & \text { NA } & 80.67769 & 16.71484 \\ \text { Probability } & 0.000000 & 0.319158 & 0.000015 & \text { NA } & 0.000000 & 0.000235 \\ \text { Sum } & 2023.560 & 995.0000 & 367.0000 & 99.00000 & 555.0000 & 61.00000 \\ \text { Sum Sq. Dev. } & 219241.8 & 768.7475 & 568.5051 & 0.000000 & 77.63636 & 23.41414 \\ \text { Observations } & 100 & 100 & 100 & 100 & & \\ & & & & & & 100\end{array}$

Table one shows the descriptive analysis of the time series properties of the variables included in the model. The descriptive statistics was carried out for the variables involved. It shows that the mean value of TBQ, INR, DER, LQT, COS and RSK are 20.44000, 10.05051, 3.707071, 1.000000, 5.606061, and 0.616162, respectively. The standard deviation of TBQ, INR, DER, LQT, COS and RSK from their respective long-term mean values every year point at 47.29864, $2.800779,2.408541,0.000000,0.890061$, and 0.488794 respectively. The probability value of Jarque-Bera statistics for all variables shows their distribution level at mean zero and constant variance. It indicated that integrated reporting and other control variables with Tobin Q were normally distributed.

Table 2: Breusch-Godfrey Serial Correlation LM Test:

\begin{tabular}{llll}
\hline F-statistic & 6.929189 & Probability & 0.113036 \\
Obs*R-squared & 13.34731 & Probability & 0.101213 \\
\hline
\end{tabular}

Source: e-view output

Table two presents the Breusch - Godfrey Serial Correlation LM test for the presence of autocorrelation. The result reveals that the probability values of $0.12(12 \%)$ and $0.10(10 \%)$ is greater than the critical value of $0.05(5 \%)$. This implies that there is no evidence for the presence of serial correlation. 
Table 3: White Heteroskedasticity Test:

\begin{tabular}{llll}
\hline F-statistic & 0.942165 & Probability & 0.496821 \\
Obs*R-squared & 9.519861 & Probability & 0.483577 \\
\hline
\end{tabular}

Source: e-view output

Table three shows the White Heteroskedasticity test for the presence of heteroskedasticity. The econometric result reveals that the probability values of $0.496(50 \%)$ and $0.483(48 \%)$ are considerably in excess of $0.05(5 \%)$. Therefore, there is no evidence for the presence of heteroskedasticity in the model.

Table 4: Ramsey RESET Test:

\begin{tabular}{llll}
\hline F-statistic & 0.067894 & Probability & 0.794795 \\
Log likelihood ratio & 0.071133 & Probability & 0.789695 \\
\hline
\end{tabular}

Source: e-view output

Table four shows the Ramsey RESET test for misspecification. The econometric result suggests that the probability values of $0.794(79 \%)$ and $0.789(79 \%)$ are in excess of the critical value of $0.05(5 \%)$. Therefore, it can be seen that there is no apparent non-linearity in the regression equation and so it would be concluded that the linear model for integrated reporting and corporate financial performance of listed insurance companies in Nigeria is appropriate.

Table 5: Output of Stationarity Test for Unit Root

\begin{tabular}{|l|l|l|l|l|}
\hline Variable & $\begin{array}{l}\text { ADF } \\
\text { Level }\end{array}$ & $\begin{array}{l}\text { ADF } \\
\text { First Difference }\end{array}$ & $\begin{array}{l}\text { Philips -Perron } \\
\text { Level }\end{array}$ & $\begin{array}{l}\text { Philip Perron } \\
\text { First Difference }\end{array}$ \\
\hline TBQ & -3.734385 & -5.913238 & -4.080133 & -5.604378 \\
\hline INR & -5.205633 & -5.117080 & -5.205577 & -5.117080 \\
\hline DER & -5.401524 & -6.382351 & -5.401524 & -6.382351 \\
\hline LQT & -4.048278 & -6.982531 & -4.016975 & -6.982531 \\
\hline COS & -4.708267 & -8.677968 & -4.791522 & -8.944514 \\
\hline RSK & -5.150467 & -6.696784 & -4.096982 & -6.626784 \\
\hline Critical Value: & & & & \\
$1 \%$ & -3.621023 & -3.626784 & -3.621023 & -3.626784 \\
$5 \%$ & -2.943257 & -2.945842 & -2.943427 & -2.945842 \\
$10 \%$ & -2.610263 & -2.611531 & -2.610263 & -2.611531 \\
\hline
\end{tabular}

Source: Eview Output for Stationarity of Data 
Table five shows the unit root test for stationarity of data. The result suggests that Tobin $Q$ (TBQ), integrated reporting (INR), corporate debt (DER), liquidity (LQT), corporate size (COS) and corporate risk (RSK) with ADF of -3.734385, -5.205633, -5.401524, -4.048278, 4.708267 and -5.150467 is less than -3.621023 for $1 \%,-2.9432257$ for $5 \%$ and -2.610263 for $10 \%$ at level data 1(0) and for Philip Perron test Tobin Q (TBQ), integrated reporting (INR), corporate debt (DER), liquidity (LQT), corporate size (COS) and corporate risk (RSK) with 4.080133, -5.205577, -5.4010524, $-4.016975,-4.791522$ and -4.096982 . The result reveals that the variables are stationary at $\mathrm{I}(0)$.

\section{Table 6: Multiple Regression Analysis}

Dependent Variable: TBQ

Method: Least Squares

Date: 03/31/21 Time: 15:58

Sample(adjusted): 1100

Included observations: 97 after adjusting endpoints

\begin{tabular}{crlrr}
\hline \multicolumn{1}{c}{ Variable } & Coefficient & Std. Error & t-Statistic & Prob. \\
\hline C & 3.275444 & 2.256856 & 1.451330 & 0.1488 \\
INR & 0.285935 & 0.095662 & 2.989017 & 0.0373 \\
DER & -0.249495 & 0.106627 & -2.339885 & 0.0268 \\
LQT & 0.216547 & 0.102573 & 2.111150 & 0.0343 \\
COS & 0.273341 & 0.123184 & 2.218965 & 0.0438 \\
RSK & 0.220526 & 0.104976 & 2.100727 & 0.0375 \\
\hline R-squared & 0.584514 & Mean dependent var & 12.99346 \\
Adjusted R-squared & 0.461358 & S.D. dependent var & 3.098167 \\
S.E. of regression & 2.888766 & Akaike info criterion & 4.997962 \\
Sum squared resid & 1226.711 & Schwarz criterion & 5.116803 \\
Log likelihood & 376.3441 & F-statistic & 5.567008 \\
Durbin-Watson stat & 2.16401 & Prob(F-statistic) & 0.000100 \\
\hline Source: $e$-view output & \multicolumn{5}{c}{}
\end{tabular}

Source: e-view output

Table six shows the multiple regression analysis for integrated reporting and corporate financial performance of listed insurance companies in Nigeria. The result suggests integrated reporting with a p-value of 0.0373 is less than 0.05 ; hence there is a positive and significant relationship between integrated reporting and corporate financial performance of insurance companies in Nigeria. The result shows that debt with a p-value of 0.0268 is less than the pvalue of 0.05; hence there is a negative and significant relationship between debt and corporate financial performance of insurance companies in Nigeria. The result reveals that liquidity with a p-value of 0.0343 is less than the critical value of 0.05 ; hence there is a positive and significant relationship between liquidity and corporate financial performance of insurance companies in Nigeria. The result suggests that corporate size with a p-value of 0.0438 is less than the critical value of 0.05 ; hence there is a positive and significant relationship between corporate size and corporate financial performance of insurance companies in Nigeria. The result shows that risk with a p-value of 0.0375 is less than the critical value of 0.05 ; hence there is a positive and significant relationship between 1 and corporate financial performance of insurance companies in Nigeria. The $\mathrm{R}^{2}$ (coefficient of determination) of 0.584514 and adjusted $\mathrm{R}^{2}$ of 0.461358 shows that the variables combined determine about $58 \%$ and $46 \%$ of corporate financial 
performance of listed insurance companies in Nigeria. The F-statistics and its probability shows that the regression equation is well formulated explaining that the relationship between the variables combined are statistically significant $(\mathrm{F}$-stat $=5.567008$; F-pro. $=0.000100)$.

\section{DISCUSSION OF FINDINGS}

Hypothesis one reveals that there is a positive and significant relationship between integrated reporting and corporate financial performance of insurance companies in Nigeria. The positive findings between integrated reporting and corporate financial performance conforms to the findings in the study of Lee \& Yeo (2016), Barth et al (2017), Adeboyegun et al, (2020) which reveal that integrated reporting positively affects the value of firms. The findings are also in line with similar positive findings in the study carried out by Iyoha et al. (2017) and Cosma et al. (2018) that integrated reporting affects firm performance positively. The result of this study negates the findings of Bijlmakers (2018), Nurkumalasari et al. (2019), Soumillion (2018) and Adeboyegun et al, (2020) that integrated reporting has no positive effect on corporate financial performance. El-Deed (2019) stated that the implication of the positive relationship between integrated reporting and corporate financial performance of the firm and the higher firm value.

Hypothesis two suggests that there is a negative and significant association between debt and corporate financial performance of listed insurance companies in Nigeria. The findings of this study is consistent with the findings of Omesi \& Appah (2021), Meier \& Laurin (2013), Cassell et al. (2012), and Akbar et al (2013), Dada (2014) that debt negatively affects the value of a firm. The results contradict the findings of De Jong et al (2011) and Gonzales (2013) revealed that debt positively influences the value of a company. Oeta, et al (2019), Timothy, et al (2020), Izevbekhai \& Odion (2018); Razali, et al (2018) findings suggest a negative insignificant relationship between financial leverage and value of a firm.

Hypothesis three shows that there is a positive and significant relationship between liquidity and corporate financial performance of insurance companies in Nigeria. The positive findings between liquidity and corporate financial performance conforms to the findings in the study of Chen, et al (2016), Van-Heerden and Van- Rensburg (2016) which reveal that liquidity positively affects the value of firms.

Hypothesis four shows that there is a positive and significant relationship between corporate size and corporate financial performance of insurance companies in Nigeria. The positive findings between corporate size and corporate financial performance conforms to the findings in the study of Oeta, et al (2019); Timothy, et al (2020) which reveal that corporate size positively affects the value of firms. The findings disagree with the study of Banchuenvijit (2012); Nwaobia, et al (2016) that showed a negative association between corporate size and value of a firm.

Hypothesis five shows that there is a positive and significant relationship between risk and corporate financial performance of insurance companies in Nigeria. The positive findings between risk and corporate financial performance conforms to the findings in the study of Mirza and Javed (2013) which reveal that risk positively affects the value of firms. In contrast, the findings of Chukwunulu et al (2019), Yunusa et al (2019) suggest that risk do not significantly affect the performance of firms. 


\section{CONCLUSION AND RECOMMENDATIONS}

This research intended to provide empirical evidence of the relationship between integrated reporting and corporate financial performance of listed insurance companies in Nigeria. The study employed data obtained from the annual reports of listed insurance companies in Nigeria for the period 2010 to 2019. The data obtained from the annual report were analysed with relevant statistical tools and the result obtained suggested that integrated reporting influences the corporate financial performance of listed insurance companies. The result of this study has implications on managers, regulatory authorities and practice in that Integrated Reporting will give managers, stakeholders, regulatory authorities better understanding of the extent to which reporting organizational overview and external environment, governance, business model, risk and opportunity, strategy and resource allocation, performance, outlook, basis of preparation and presentation in the determination of firm performance. The study concluded that integrated reporting is useful in the determination of the corporate financial performance of listed companies in Nigeria.

The following recommendations were provided:

1. Managers of listed firms in Nigeria should commence the adoption of integrated reporting practices on a voluntary basis.

2. The Financial Reporting Council of Nigeria (FRCN) should fast-track a new framework for corporate reporting that includes substantial elements of integrated reporting in Nigeria.

3. The Financial Reporting Council of Nigeria (FRCN) should make the adoption of integrated reporting compulsory across companies listed on the Nigerian Stock Exchange in a bid to improve the relationship between integrated reporting and financial performance of firms.

4. Corporate annual reports in Nigeria should include non-financial information of longrun forecast as a means to educate stakeholders on the long run future of a company as a going concern.

\section{REFERENCES}

Abreu, R. (2016). From accounting to firm value. Procedia Economics and Finance 39,685692.

Adams, C.A., Potter, B., Singh, P.J. \& York, J. (2016). Exploring the implications of integrated reporting for social investment (disclosures), The British Accounting Review, 48(3), 283-296.

Adegbie, F.F., Akintoye, I. R. \& Isiaka, B. (2019). Evaluation of integrated reporting and the value of listed manufacturing firms in Nigeria, European Journal of Accounting, Auditing \& Finance Research, 7(7), 31-59.

Adegbie, F.F., Akintoye, I.F. \& Olusanjo, O.R. (2019). Effect of integrated reporting practices on corporate disclosure and transparency in Nigeria quoted manufacturing companies, International Journal of Economics \& Business Review, 7(6), 72-80. 
Adegboyegun, A.E., Alade, M.E., Ben-Caleb, E., Ademola, A.O., Eluyela, D.F. \& Oladipo, O.A. (2020), Integrated reporting and corporate performance in Nigeria: Evidence from the banking industry, Cogent Business \& Management, 7:1, 1736866.

Ahmed Haji, A. \& Anifowose, M. (2017), "Initial trends in corporate disclosures following the introduction of integrated reporting practice in South Africa", Journal of Intellectual Capital, 18(2), 373-399.

Albetairi, H. T. A., Kukreja, G., \& Hamdan, A. (2018). Integrated reporting and financial performance: Empirical evidence from Bahraini listed insurance companies. Accounting and Finance Research, 7(3), 102-110. http://doi.org/10.5430/afr.v7n3p102

Alessandro, L., Gaia, M., \& Riccardo, S. (2018), "Integrated reporting and narrative accountability: the role of preparers", Accounting, Auditing \& Accountability Journal, 31(5), 1381-1405.

Aluchna, M., Hussain, N., \& Roszkowska-Menkes, M. (2019). Integrated reporting narratives: The case of an industry leader. Sustainability, 11(976), 1-16. doi:10.3390/su11040976.

Appah, E. (2020). Research methodology: Integration of principles, methods and techniques, Ezevin Printing and Publishing.

Ara, M. \& Harani, B. (2020). Integrated reporting insights: Why organisations voluntarily reports? International Journal of Scientific \& Technology Research, 9(1), 3055-3069.

Azmat, Q.-U.-A. (2014) Firm value and optimal cash level: Evidence from Pakistan. International Journal of Emerging Markets, 9 (4), 488-504.

Baboukardos, D., \& Rimmel, G. (2016). Value relevance of accounting information under an integrated reporting approach: A research note. Journal of Accounting and Public policy, 35(4), 437-452.

Bebeji, A., Mohammed, A. \& Tanko, M. (2015). The effect of board size and composition on the financial performance of banks in Nigeria. African Journal of Business Management, 9(16), 590598.

Bijlmakers, L. (2018). The influence of integrated reporting on firm value [M.Sc. Thesis]. University of Amsterdam.

Camilleri, M. A. (2018). Theoretical insights on integrated reporting: The inclusion of nonfinancial capitals in corporate disclosures. Corporate Communications: An International Journal, 23 (4), 567-581. https://doi.org/10.1108/CCIJ-01-2018-0016

Chen, R.-R., Yang, T-H \& Yeh, S-K. (2016). The liquidity impact on firm values: The evidence of Taiwan's banking industry. Journal of Banking \& Finance.

Chukwunulu, J.I., Ezeabasili, V.N. \& Igbodika, M.A.N. (2019). Risk management and performance of banks in Nigeria (1994 - 2016). IIARD International Journal of Banking and Finance Research, 5(1), $64-72$.

Cosma, S., Soana, M. G., \& Venturelli, A. (2018). Does the market reward integrated report quality? African Journal of Business Management, 12(4), 78-91. http:// doi.org/10.5897/AJBM2017.8469.

Damodaran, A. (2005). Valuation approaches and metrics: A survey of the theory and evidence. Foundations and Trends in Finance, 1(8) 693-784.

De Jong, A., Verbeek, M. \& Verwijmeren, P. (2011). Firms' debt-equity decisions when the static tradeoff theory and the pecking order theory disagree. Journal of Banking \& Finance, 35 (5),1303- 1314.

Dumay, J., Torre, M., \& Farneti, F. (2018). Developing trust through stewardship: Implications for intellectual capital, integrated reporting, and the EU Directive 
2014/95/EU. Journal of Intellectual Capital, 20(1), 11-39. https://doi.org/10.1108/JIC06-2018-0097

Dumay, J.C. (2016). A critical reflection on the future of intellectual capital: From reporting to disclosure. Journal of Intellectual Capital, 17, 168-184.

Egbunike, F.C. \& Abiahu, M-F, C. (2017). Audit firm report and financial performance of money deposit banks in Nigeria", The Nigerian Accountant, 50(1): 25 - 39.

El-Deeb, M.S. (2019). The impact of integrated reporting on firm value and performance: Evidence from Egypt, Alexandria Journal of Accounting Research, 3(2), 1-34.

Feng, T., Cummings, L. \& Tweedie, D. (2017). Exploring integrated thinking in integrated reporting - an exploratory study in Australia. Journal of Intellectual Capital, 18(2), 330353.

Fernando, K., Dharmawati, R., Sriani, D., Shauki, S.E., \& Diyarty, V. (2017). Does integrated reporting approach enhance the value relevance of accounting information?: Evidence from Asian firms, Advances in Economics, Business and Management Research, 55: 112 - 117.

Freeman, R. E. (1984). Strategic management: A stakeholder approach. London: Pitman.

Golec, J. \& Gupta, N.J. (2014). Do investments in intangible customer assets affect firm value? The Quarterly Review of Economics and Finance, 54 (4),513-520.

González, V. M. (2013). Leverage and corporate performance: International evidence. International Review of Economics \& Finance, 25,169-184.

Gray, R., Owen, D., \& Adams, C. (1996). Accounting \& accountability: changes and challenges in corporate social and environmental reporting. Prentice-Hall.

Gujurati, D.N. and Porter, D.C. (2009). Basic Econometric (5th ed.). McGraw Hill.

Hidayat, R., Wahyudi, S., Muharam, H., Shaferi, I., \& Puspitasari, I. (2019). The improved level of firm value with liquidity, debt policy and investment in Indonesian emerging market, Revista Espacious, 40(40), 1-9.

Hoque, M.E. (2017). Why company should companies adopt integrated reporting? International Journal of Economics and Financial Issues, 7(1), 241 - 248.

Hsiao, P.K., \& Kelly, M., (2018). Investment considerations and impressions of integrated reporting: Evidence from Taiwan, Sustainability Accounting, Management and Policy Journal, 9(1), 2-28

IIRC (2015). Applying the integrated reporting concept of 'capitals' in the banking industry. IR Banking Network Paper Series.

IIRC. (2013). The international integrated reporting framework. http://www.theiirc.org/wpcontent/uploads.

Isik, O. \& Ince, A. R. (2016). Board size, board composition and performance: an investigation on Turkish Banks. International Business Research, 9(2), 74- 84.

Iyoha, F. O., Ojeka, S. A., \& Ogundana, O. M. (2017). Bankers' perspectives on integrated reporting for value creation: Evidence from Nigeria. Banks and Bank System, 12(2), 100-105. http://doi.org/10.21511/bbs.12(2).2017.10.

Izevbekhai, M.O. \& Odion, A.O. (2018). Tax planning and firm value. Nigerian Academy of Management Journal, 13(1), 94-119.

Jensen, M. C., \& Meckling, W. H. (1976). Theory of the firm: Managerial behaviour, agency costs and ownership structure. Journal of Financial Economics, 1(1), 305-360. http://doi.org/10.1016/0304-405X(76) 90026-X.

Jeroe, A. (2016). Integrated reporting, non-financial information and financial performance [M.Sc. Thesis]. Erasmus University. 
Kajola, S.A., Onaolapo, A.A. \& Adelowotan, M.O. (2017). The effects of corporate size on financial performance of Nigeria listed firms, Nigeria Journal of Management Sciences, 6(1), 204-215.

Kilic, M. \& Kuzey, C. (2018a). Assessing current company reports according to the IIRC Integrated Reporting Framework. Meditari Accountancy Research, 26(2), 305-333.

Kilic, M. \& Kuzey, C. (2018b). Determinants of forward-looking disclosures in integrated reporting. Managerial Auditing Journal, doi.org/10.1108/MAJ-12-2016-1498.

Lee, K. \& Yeo, G.H. (2016). The Association between Integrated Reporting and Firm Valuation. Review of Quantitative Finance and Accounting, 47(4), 1221-1250.

Lindblom, C. K. (1994). The implications of organizational legitimacy for corporate social performance and disclosure. Critical Perspectives on Accounting Conference Papers, New York.

Malik, M., Wan, D., Amad, M. I. \& Naseem, M. A. (2014). Role of board size in corporate governance and firm performance applying Pareto approach, is it cultural phenomena? Journal of Applied Business Research, 30(5), 1395-1406.

McNally, M.A., Cerbone, D. \& Maroun, W. (2017), "Exploring the challenges of preparing an integrated report", Meditari Accountancy Research, 25(4), 481-504.

Meier, I., Yves, B. \& Claude, L. (2013). Financial flexibility and the performance during the recent financial crisis. International Journal of Commerce and Management 23 (2):7996.

Mirza, S.A. \& Javed, A. (2013). Determinants of financial performance of a firm: Case of Pakistan Stock Market. Journal of Economics and International Finance, 5(2), 43-52.

Nurkumalasari, I.S., Restuningdish, N. \& Sidharta, E.A. (2019). Integrated reporting disclosure and its impact on firm value: Evidence in Asia, International Journal of Business, Economics \& Law, 18(5), 99 - 108.

Nwaobia, A., Kwarbai, J., \& Ogundajo, G. (2016). Tax Planning and Firm Value: Empirical evidence from Nigerian consumer goods industrial sector. Research Journal of Finance and Accounting, 7(12), 172-183.

Oeta, S.M., Kiai, R. \& Muchiri, J. (2019). Influence of tax planning on financial performance of manufacturing companies listed at Nairobi Securities Exchange. International Journal of Research in Business and Social Sciences, 8(6), 262-269.

Olusanjo, O.R., Adegbie, F.F. \& Akintoye, I.R. (2019). Effect of integrated reporting practices on improved shareholders relationships in Nigeria quoted manufacturing companies, International Journal of Business \& Management Invention, 8(7), 39-46.

Omesi, I. \& Appah, E. (2021). Corporate tax planning and firm value of listed consumer goods companies in Nigeria. IOSR Journal of Business and Management, 23(2), 42-51.

Onsongo, S.K., Muatha, S.M.A. \& Mwangi, L.W. (2020). Financial risk and financial performance: Evidence and insights from commercial and services listed companies in Nairobi Securities and Exchange, Kenya. International Journal of Financial Studies, 8, $51,1-15$.

Prombutr, W., Lockwood, L. \& Diltz, J.D. (2010). Investment Irreversibility, cash flow risk, and value-growth stock return effects. Financial Review 45 (2), 287-305.

Razali, M.W.M., Ghazali, S.S., Lunyai, J. \& Hwang, J.Y.T. (2018). Tax planning and firm value: evidence from Malaysia. International Journal of Academic Research in Business and Social Sciences, 8 (11), 210-222.

Rinaldi, L. et al. (2018). Evaluating the integrated reporting ourney: Insights, gaps and agendas for future research. Accounting, Auditing \& Accountability Journal, 31(5), $1294-1318$. 
Scantlebury, K. \& Alleyne, P. (2015). A content analysis of risk management disclosures in Barbadian Public Limited Companies' Annual Report. Journal of Eastern Caribbean Studies, 40(2), 127-165.

Serafeim, G. (2015), Integrated reporting and investor clientele. Journal of Applied Corporate Finance, 27(2), 34-51.

Soumillion, V. (2018). The value relevance of integrated reporting in South Africa (M.Sc. Dissertation). Universiteit Gent.

Sukhari, A., \& de Villiers, C. (2018). The influence of integrated reporting on business mode and strategy disclosures. Australian Accounting Review, 1-31.

Suttipun, M. (2017). The effect of integrated reporting on corporate performance: Evidence from Thailand. Corporate Ownership and Control, 15(1), 133-142. http://doi.org/10.22495/cocv15i1art13

Timothy, O.U., Izilin, M.O. \& Ndifereke, B.A. (2020). Corporate tax planning, board compensation and firm value. Accounting and Taxation Review, 4(3), 11-28.

Van Bommel, K. (2014). Towards a legitimate compromise?: An exploration of integrated reporting in the Netherlands. Accounting, Auditing and Accountability Journal, 27(7), 1157-1189.

Van Heerden, J. D., \& Van Rensburg, P. (2016). The impact of liquidity on the cross section of equity returns on the Johannesburg Securities Exchange. Economics, Management \& Financial Markets, 11(2), 59-86.

Yinusa, O.G., Ismail, A., Yulia, R. \& Olawale, L.S. (2019). Capital structure and firm performance in Nigeria, African Journal of Economic Review, 7(1), 31-57. 


\section{APPENDIX}

\section{Integrated Reporting Index Scoring Table}

\begin{tabular}{|l|l|c|c|}
\hline $\begin{array}{l}\text { IIRC Framework } \\
\text { Element }\end{array}$ & Basis of Scoring & $\begin{array}{l}\text { Maximu } \\
\text { m Score }\end{array}$ & $\begin{array}{l}\text { Total } \\
\text { Maximum } \\
\text { Score }\end{array}$ \\
\hline $\begin{array}{l}\text { Overview and } \\
\text { External } \\
\text { Environment }\end{array}$ & $\begin{array}{l}\text { Vision and Mission } \\
\text { External Environment }\end{array}$ & 1 & 2 \\
\hline Governance & $\begin{array}{l}\text { Report on Directors prolife } \\
\text { Report on Directors Remuneration } \\
\text { Report on Board \& Audit Committee }\end{array}$ & 1 & \\
\hline Business Model & $\begin{array}{l}\text { Report of Specific Business Model } \\
\text { Adopted Inclusion of Business Model in } \\
\text { Report }\end{array}$ & 1 & 3 \\
\hline Risk \& Opportunity & $\begin{array}{l}\text { Report of Risk resource } \\
\text { Report of Opportunities }\end{array}$ & 1 & 2 \\
\hline $\begin{array}{l}\text { Strategy } \\
\text { Resource Allocation }\end{array}$ & $\begin{array}{l}\text { Inclusion of strategy and } \\
\text { allocation }\end{array}$ & 1 & 2 \\
\hline Performance & $\begin{array}{l}\text { Environmental reporting } \\
\text { CSR Performance reporting }\end{array}$ & 1 & 1 \\
\hline Financial performance & 1 & 1 \\
\hline Outlook & Report of future forecast & 1 & 1 \\
\hline Basis of preparation & Report of basis of preparation & $15(100 \%)$ \\
\hline Total & & 1 & 3 \\
\hline
\end{tabular}

Source: Nurkumalasari, et al (2019); Olusanjo, et al (2019); El-Deeb, (2019); Adegboyegun, et al (2020) 